\title{
Review on Applications of Genetic Engineering And Cloning in Farm animals
}

\author{
Eyachew Ayana ${ }^{1}$, Gizachew Fentahun ${ }^{2}$, Ayalew Negash ${ }^{3 *}$, Fentahun Mitku${ }^{1}$, Mebrie Zemene ${ }^{3}$ and Fikre Zeru ${ }^{4}$ \\ ${ }^{1}$ Candidate of Veterinary medicine, University of Gondar, Ethiopia \\ ${ }^{2}$ Candidate of Veterinary medicine, Samara University, Ethiopia
}

${ }^{3}$ Lecturer at University of Gondar, University of Gondar, Ethiopia

${ }^{4}$ Samara University, Ethiopia

Submission: July 10, 2017; Published: October 02, 2017

*Corresponding author: Ayalew Negash, Lecturer at University of Gondar, College of Veterinary Medicine and science, University of Gondar, P.O. 196, Gondar, Ethiopia, Email: ayalewnegash2014@gmail.com

\begin{abstract}
Genetic engineering involves producing transgenic animal's models by using different techniques such as exogenous pronuclear DNA microinjection in zygotes, injection of genetically modified embryonic stem cells into blastocysts and retrovirus mediated gene transfer. It is highly applicable and crucial technology which involves increasing animal production and productivity, increases animal disease resistance and biomedical application. Cloning involves the production of animals that are genetically identical to the donor nucleus. The most commonly applied and recent technique is somatic cell nuclear transfer in which the nucleus from body cell is transferred to an egg cell to create an embryo that is virtually identical to the donor nucleus. There are different applications of cloning which includes: rapid multiplication of desired livestock, animal conservation and research model. However, at present it is an inefficient process due to parturition difficulties, placental abnormalities and post-natal viabilities. Beside to this Food safety, animal welfare, public and social acceptance and religious institutions are the most common challenges for the development of this technology. In developing country including Ethiopia the science is not yet conceived and the concerned body should pay great attention to such valuable aspects of biotechnological advancements.
\end{abstract}

Keywords: Cloning; Genetic engineering; Nuclear transfer; Transgenic animal; Animal welfare

Abbreviations: DNA: Deoxy ribose Nucleic Acid; SCNT: Somatic Cell Nuclear Transfer; ES: Embryonic stem; EGF: Epidermal Growth factor; TGF: Transforming Growth Factor; MMA: Mastitis Metritis Agalactia; NT: Nuclear Transfer; FDA: Food and Drug Administration; MAS: Marker-Assisted Selection; MHC: Major Histocompatibility Complex

\section{Introduction}

Biotechnology has contributed to the genetic improvement of farm animals for decades, through artificial insemination and embryo transfers. The advent of modern biotechnology provides new avenues for genetic improvement in the production of farm animals. During the past decades, however, the term biotechnology has come to be associated more with molecularbased technologies, such as gene cloning and genetic engineering [1]. Now a days, biotechnology typically genetic engineering and cloning play an important role on both basic and applied research becoming an essential tool for the understanding of the biology and development of animal biotechnology. Such technology presents a wide range of applications, such as the production of biopharmaceuticals, studies on gene expression and its regulation, the improvement of animal production, production of herds resistant to specific diseases and many other biomedical and medical purposes [2].
Through the biotechnology of gene therapy, scientists are making efforts at curing genetic diseases by attempting to replace defective genes with the correct version and also used to produce more effective and efficient vaccines, therapeutic antibodies, antibiotics and other pharmaceuticals. There are more than 370 drug products and vaccines obtained through biotechnology currently in clinical trials, targeting more than 200 diseases including various cancers, Alzheimer's disease, heart disease, diabetes, multiple sclerosis and arthritis [3].

A genetically engineered or transgenic animal is an animal that carries a known sequence of recombinant Deoxy ribose Nucleic Acid (DNA) in its cells, and which passes that DNA onto its offspring [4]. Recombinant DNA refers to DNA fragments that have been joined together in a laboratory. The resultant recombinant DNA construct is usually designed to express the 
proteins that are encoded by the genes included in the construct, when present in the genome of a transgenic animal. Because the genetic code for all organisms is made up of the same four nucleotide building blocks, this means that a gene makes the same protein whether it is made in an animal, a plant or a microbe. Proteins that have been expressed in transgenic animals include therapeutic proteins for the treatment of human diseases [5]; proteins that enable animals to better resist disease and proteins that result in the production of more healthful animal products (milk, eggs or meat) for consumers [6].

Cloning refers to producing genetically identical individual to donor cells and copying gene, which involves the creation of an animal or individual that derives its genes from a single other individual; it is also referred as asexual reproduction [7]. Cloned offspring in human and farm animals sometimes produced in nature when early embryo splits in to two (or sometime, more) species of just a few days after fertilization, before the cells have become too specialized. However, there are a number of artificial methods to produce genetically identical mammals. Of these, the nuclear cloning technology is considered to have the greatest potential application for animal agriculture and medicine [8].

Scientists have been attempting to clone animals through nuclear transfer of somatic cell (SCNT) for several decades. SCNT is an efficient way to create herds of genetically modified cloned animals, preservation of endangered species, production of human therapeutic proteins in genetically modified clone animals, use of genetically modified cloned animals as a source of organs for human transplantation, gaining a better understanding of cellular differentiation and reprogramming capabilities that could be the basis for human cellular therapies, and better models to study new treatments for human disease. However, SCNT cloning thus far has been very inefficient process and cloned animals have exhibited serious health problems [9].

The genetic engineering of animals has increased significantly in recent years, and the use of this technology brings with it ethical issues, some of which relate to animal welfare defined by the World Organization for Animal Health [10]. It is important to try to reflect societal values within scientific practice and emerging technology, especially publicly funded efforts that aim to provide societal benefits, but that may be deemed ethically contentious [11]. Even though, genetic engineering and cloning are interesting sciences with wide range of application, they have also some uncertainties and challenges and further investigation are needed to develop the technology. Therefore the objectives of this seminar paper area follow

- $\quad$ To review the application of genetic engineering and cloning,

- $\quad$ To highlight the concepts, techniques and challenges of genetic engineering and cloning.

\section{Literature Review}

\section{History of genetic engineering and cloning time line}

Genetic modification caused by human activity has been occurring since around 12,000 BC, when humans first began to domesticate organisms. Genetic engineering is the direct manipulation of an organism's genome using certain biotechnology techniques that have only existed since the 1970s. Genetic engineering as the direct transfer of DNA from one organism to another was first accomplished by Herbert Boyer and Stanley Cohen in 1973 [12].

Human directed genetic manipulation was occurring much earlier, beginning with the domestication of plants and animals through artificial selection. The dog is believed to be the first animal domesticated, possibly arising from a common ancestor of the wolf. The first genetically modified animal was a mouse created in 1973 by Rudolf Jahnish [12]. Cloning research has been underway since the 1890s. The first animal cloning research was an attempt to produce identical organisms by splitting animal embryos at early stages of development. Work continued in the field of animal cloning and in 1952 the nuclear transfer procedure was invented. Work with nuclear transfer resulted in the successful cloning of many species from embryonic nuclei. In the 1980's, nuclear transfer was used to clone cattle and sheep using cells taken directly from early embryos [13].

Table1: Cloning time line.

\begin{tabular}{|c|c|c|}
\hline Cloned year & Name of cloned animal & References \\
\hline 1996 & Sheep (Dolly) & Wilmut et al. [14] \\
\hline 1998 & Cow (Noto and Kaga) et al. [67] \\
\hline 1999 & Goat (Mira) & Chesné et al. [61] \\
\hline 2000 & Polejaeva et al. [43] \\
\hline 2002 & Cat & Lee et al. [62] \\
\hline 2003 & Horse (Prometea et al. [15] \\
\hline 2004 & Buffalo & Wakayama et al. [66] \\
\hline 2005 & Ferret (Libby and Lilly) et al. [63] \\
\hline 2006 & Camel (Injaz) & Golovan et al. [64] \\
\hline 2009 & Zhang et al. [68]
\end{tabular}


In 1995, living lambs, named Megan and Morag, were created for the first time from cultured cells. However, prior to 1997 the word clone conjured up images of creatures from Jurassic Park or other works of science fiction in the minds of most people. In July of 1996, Scottish scientists created the first animal cloned from an adult cell. On July 5, 1996, Dolly the sheep was born at the Rollin Institute in Edinburgh Scotland. The announcement of her birth in early 1997 shocked the scientific community and stirred debate over the possibility of cloning humans [14]. A process known as cell nuclear replacement created Dolly by transferring a mammary cell of a six-year-old white Welsh Mountain sheep into the egg cell of a Scottish blackface ewe. Since Dolly's birth, several other species have successfully been cloned including: mice, cattle, sheep, pigs, goats, rabbits and a cat [15] (Table 1).

\section{Genetic engineering (transgenic animal) model}

Genetic engineering is the name of a group of techniques used for direct genetic modification of organisms or population of organisms using recombination of DNA. These procedures are of use to identify, replicate, modify and transfer the genetic material of cells, tissues or complete organisms. Most techniques are related to the direct manipulation of DNA oriented to the expression of particular genes [16].

In a broader sense, genetic engineering involves the incorporation of DNA markers for selection (marker-assisted selection, MAS), to increase the efficiency of the so called traditional methods of breeding based on phenotypic information [17]. Transgenic animals can be created to gain knowledge of gene function and further decipher the genetic code, study gene control in complex organisms, build genetic disease models, improve animal production traits, and produce new animal products [18].

\section{Technique of genetic engineering}

Exogenous pronuclear DNA microinjection in zygotes: Micro-injection is the first successful approach for the creation of transgenic animals based on the injection of a foreign DNA construct into a fertilized oocyte. The construct integrates randomly into the host oocyte genome, subsequently the zygote continues embryonic development and the embryo is transferred to a foster mother and eventually develops to a transgenic animal. However, this method has strong limitations: on average, less than $1 \%$ of embryos injected and $10 \%$ of animals born are transgenic, genes can only be added, not replaced or deleted, and multiple copies of the transgene are inserted at random, hindering the correct regulation of gene expression and possibly interfering with endogenous gene function. This requires large amounts of oocytes to be injected, as the overall efficiency of the process is very low [19].

Injection of genetically modified embryonic stem (ES) cells into blastocysts

Embryonic stem cells are derived from embryos at a very early stage (the blastula), and possess the important characteristic of pluripotency. Pluripotency is the ability of these cells to differentiate to any of the cell types and tissues found in the adult organism. Embryonic stem cells can be grown in culture for many passages and can be subjected to transformation with transgene constructs, resulting in modifications of their genome. The constructs used not only permit the selection of successfully transformed cells, but also allow gene targeting to be accomplished. Thus, genes can be specifically introduced, replaced or deleted (so-called knock-ins and knock-outs) [20].

Injection of genetically modified embryonic stem (ES) cells into blastocysts, mainly through the feature of gene targeting, allows a broad variety of genetic modifications to be introduced. For many years, several laboratories worldwide have tried to produce ES cells from farm animals, and although some success has been claimed, no robust and reproducible method has been published. Indeed, even in mice the production of ES cells is a costly and labor-intensive technology [18].

\section{Retrovirus mediated gene transfer}

Transgenesis may also be accomplished by employing virusderived vectors, namely vectors based on the retrovirus-class of lenti viruses [21]. Genes that are essential for viral replication are deleted from the viral genome, maintaining only the capacity for integration of the viral genome into the host genome. The parts of the viral genes can replaced by the transgene of interest, then Viruses carrying the modified gene are produced in-vitro and subsequently injected into the perivitelline space of the zygote, resulting in infection of the zygote and integration of the viral genome into the host genome. Transgenesis rates reaching up to $100 \%$ of injected embryos have been described [22].

Major drawbacks of this method are a limited transgene size and random transgene integration. Random and possibly multiple transgene integration may lead to position effects, disturbance of the host genome and dose effects, as is the case with pronuclear injection. Solving these problems holds great promise for the further development and application of lentiviral vectors [22].

\section{Uses of animal genetic engineering}

\section{Increase animal disease resistance}

Genetic engineering of agricultural animals has the potential to improve disease resistance by introducing specific genes into livestock. Identification of single genes in the major histocompatibility complex (MHC), which influence the immune response, was instrumental in the recognition of the genetic basis of disease resistance/susceptibility [23]. The application of transgenic technology to specific aspects of the immune system should provide opportunities to genetically engineer livestock that are healthier and have superior disease resistance. One specific example where transgenesis has been applied to disease resistance in livestock is the attempt to produce cattle resistant to mastitis. Lysostaphin is an antimicrobial peptide that protects mammary glands against Staphylococcus aurous infection by killing the bacteria in a dose-dependent manner. Transgenic dairy cows that secrete lysostaphin into their milk have been produced 
to address the mastitis issue. The application of nuclear transfer technology, or cloning, will enable the augmentation of beneficial alleles and/or the removal (via gene knock-out) of undesirable alleles associated with disease resistance or susceptibility. By knocking-out the intestinal receptor for the K88 antigen lead to the absence of this antigen has been shown to confer resistance to infection of K88-positive E. coli [24].

\section{Enhance growth and meat trait}

Altering the fat or cholesterol composition of the carcass is valuable benefit that can be delivered via genetic engineering. By changing the metabolism or uptake of cholesterol and/ or fatty acids, the content of fat and cholesterol of meats, eggs and cheeses could be lowered. There is also the possibility of introducing beneficial fats such as the omega- 3 fatty lipoprotein receptor gene and hormones like leptin are also potential targets that would decrease fat and cholesterol in animal products [6].

The use of genetic engineering to improve feed efficiency and/or appetite could profoundly impact livestock production and deliver significant benefits to producers, processors, and consumers. Increased uptake of nutrients in the digestive tract, by alteration of the enzyme profiles in the gut, could increase feed efficiency. The ability to introduce enzymes such as Phytase or xylanase into the gut of species where they are not normally present, such as swine or poultry, is particularly attractive [25].

The introduction of phytase would increase the bioavailability of phosphorus from phytic acid in corn and soy products. Golovan and his colleagues reported that the production of transgenic pigs expressing salivary phytase as early as seven days of age. The salivary phytase provided essentially complete digestion of the dietary phytate phosphorus in addition to reducing phosphorus output in waste by up to $75 \%$. Furthermore, transgenic pigs required almost no inorganic phosphorus supplementation to the diet to achieve normal growth. The use of phytase transgenic pigs in commercial pork production could result in significantly decreased environmental phosphorus pollution from livestock operations [25].

\section{Improve wool production}

The control of the quality, color, yield and ease of harvest of hair, wool and fiber for fabric and yarn production has been an area of focus for genetic engineering in livestock. The manipulation of the quality, length, fineness and crimp of the wool and hair fiber from sheep and goats has been examined using transgenic methods. Transgenic methods also allow improvements to fiber elasticity, surface and strength. Decreasing the surface interactions between fibers could decrease shrinkage of garments made from such fibers [26].

\section{Desired milk yield and composition}

Advances in recombinant DNA technology have provided the opportunity either to improve the composition of milk or to produce entirely novel proteins in milk. These changes may add value to, as well as increase, the potential uses of milk.
The improvement of livestock growth or survivability through the modification of milk composition requires production of genetically engineered animals that:

1) Produce a greater quantity of milk,

2) Produce milk of higher nutrient protein content. The major nutrients in milk are protein, fat and lactose.

Elevation of these components can improve growth and health of the developing offspring that consumer the enhanced milk [27].

Changing milk composition may improve animal growth is the addition or supplementation of beneficial naturally occurring hormones, growth factors or bioactive factors to the milk through the use of genetic engineering. It has been suggested that bioactive substances in milk possess important functions in the neonate with regard to regulation of growth, development and maturation of the gut, immune system and endocrine organs [28]. Transgenic alteration of milk composition has the potential to enhance the production of certain proteins and/or growth factors that are deficient in milk. The increased expression of a number of these proteins in milk may improve growth, development, health and survivability of the developing offspring. Some of these factors are insulin-like growth factor 1 (IGF-1), epidermal growth factor (EGF), transforming growth factor (TGF) and lactoferrin [29].

The properties' of milk that bear consideration for modification are those that affect human and animal health. It has been shown that specific antibodies can be produced in genetically engineered animals. It is possible to produce antibodies in the mammary gland that are capable of preventing mastitis in cattle, sheep and goats and mastitis metritis agalactia (MMA) in pigs, and/or antibodies that aid in the prevention of domestic animal or human diseases. Other role is to increase proteins that have physiological roles within the mammary gland itself such as lactalbumin, lysozyme, lysostaphin or other antimicrobial peptides.

It is important to consider the use of transgenics to increase specific components, which are already present in milk for manufacturing purposes. An example might be to increase one of the casein components in milk. This could increase the value of milk in manufacturing processes such as production of cheese or yogurt. One might also alter the physical properties of a protein such as casein [30].

\section{Human cell-based therapies}

Direct applications of Nuclear Transfer (NT) technology in human therapies, principally therapeutic cloning as opposed to human reproductive cloning [31]. Patients with diseases or disorders in tissues like insulin-dependent diabetes, muscular dystrophy, spinal cord injury, certain cancers and various neurological disorders, including Parkinson's disease could potentially generate their own immunologically compatible cells for transplantation, which would offer lifelong treatment 
without tissue rejection [32]. Initially, this approach could employ human NT and embryonic stem cells but, the use of this technique in human is controversial. In the longer term, however, fundamental understanding of reprogramming will enable one cell type to be directly trans-differentiated into another cell type specifically required for cell-based therapy [33].

One major application of animal transgenesis is the production of pharmaceutical products, also known as animal pharming. Since many human proteins cannot be produced in microorganisms and production in cell culture is often laborintensive with low yields, the production of biopharmaceuticals in transgenic animal bioreactors is an attractive alternative [34]. Many human proteins cannot be produced in micro-organisms, since they lack post-translational modification mechanisms that are essential for the correct function of many human proteins. Pharmaceutical proteins or other compounds can be produced in a variety of body fluids, including milk, urine, blood, saliva, chicken egg white and seminal fluid, depending on the use of tissue-specific promoters [35].

\section{Protein based drug}

Protein-based drugs differ from protein products synthesized in the blood in that they are produced in-vivo by other organs. This technology is even being applied to the development of complex proteins such as monoclonal antibodies as well as many other important human replacement proteins and protein drugs such as polyclonal antibodies and plasminogen activator [3]. Researchers recently created a line of transgenic swine that produce recombinant human erythropoietin a naturally occurring human hormone that boosts the body's production of red blood cells. The transgenic swine produced the hormone in their milk through a potentially more efficient and lower cost process than traditional methods patients with diseased kidneys no longer able to produce the protein, as well as cancer patients being treated with chemotherapy who develop anemia as a consequence of bone marrow depletion from their cancer drug regimens. Erythropoetin-based drugs are some of the most widely used protein-based drugs, and are expensive to manufacture [36].

\section{Xenotransplantation}

Xenotransplantation is the transplantation of organs or cells from one species to another. Human to human transplantation are sometimes difficult due to scarcity of donor organ. Pig is considered the preferred candidate for xenotransplantation because of physiological compatibility and breeding characteristics. Large numbers of pathogen free pigs can be raised to provide organs for transplantation in to humans [37]. However, one of the problems associated with using pig organs for xenotransplantation is that the immune system of the human recipient attacks the transplanted organ, causing transplant rejection. Pigs naturally produce a sugar, called $\alpha 1$, 3 -galactosyltransferase ( $\alpha$ GalT) on the surface of their cells, which the human immune system recognizes as foreign [38]. The human immune system then forms antibodies to attack the cells which produce that sugar, resulting in tissue rejection. Through the use of genetic engineering and cloning, scientists have created pigs which are deficient for $\alpha$ GalT and do not produce it on the surface of their cells. Transfer of these genetically engineered tissues and organs into baboon recipients has increased the length of time before the organs are rejected by the recipient's immune system.

\section{Techniques of cloning}

Cloning is a powerful technique by producing genetically identical individuals and potentially it could be used for multiplication of elite animals and minimizes the genetic variation in experimental animals. It can be used for the conservation as well as propagation of endangered species. It may be used also as a tool for the production of stem cells for therapeutic purposes, as therapeutic cloning. Cloning using somatic cells offers opportunities to select and multiply animals of specific merits. Cloned offspring in humans and animals are sometimes produced in nature when the early embryo splits in two (or sometimes, more) pieces just a few days after fertilization, before the cells have become too specialized. However, there are also a number of artificial methods to produce genetically identical mammals. Of these, the nuclear cloning methodology is considered to have the greatest potential application for animal agriculture and medicine [8].

\section{Somatic Cell Nuclear Transfer (SCNT)}

The transfer of a cell nucleus from a body cell into an egg from which the chromosomes have been removed or inactivated; is method used for cloning of organisms. Once the genome transferred with the egg cell then one cell embryo is created and the process of cloning is completed and further development of the clone can occur [39] (Figure 1).

\section{Embryo splitting (embryo twining)}

Embryo splitting may be considered the first true cloning procedure involving human intervention, and was first described by Willesden and Polge in 1981, when monozygotic twin calves were produced. Embryo splitting or the mechanical separation of cells can be used in very early embryos. Two-cell embryos derived from either in vitro fertilization or embryo rescue following in vivo fertilization are held in place with micropipettes under a microscope.

The zonapellucida (the clear layer of protein surrounding the oocyte and fertilized ovum) of these embryos is opened, and the two-celled embryo is then split into individual cells with a finely drawn needle or pipette. One of the cells is left in the original zonapellucida and the other is either placed into an empty zonapellucida or allowed to develop without a zonapellucida. These so-called demi-embryos can be cultured in vitro for a few days, inspected for appropriate growth and then transferred directly to synchronized recipient dams or frozen for future use (Figure 2). 


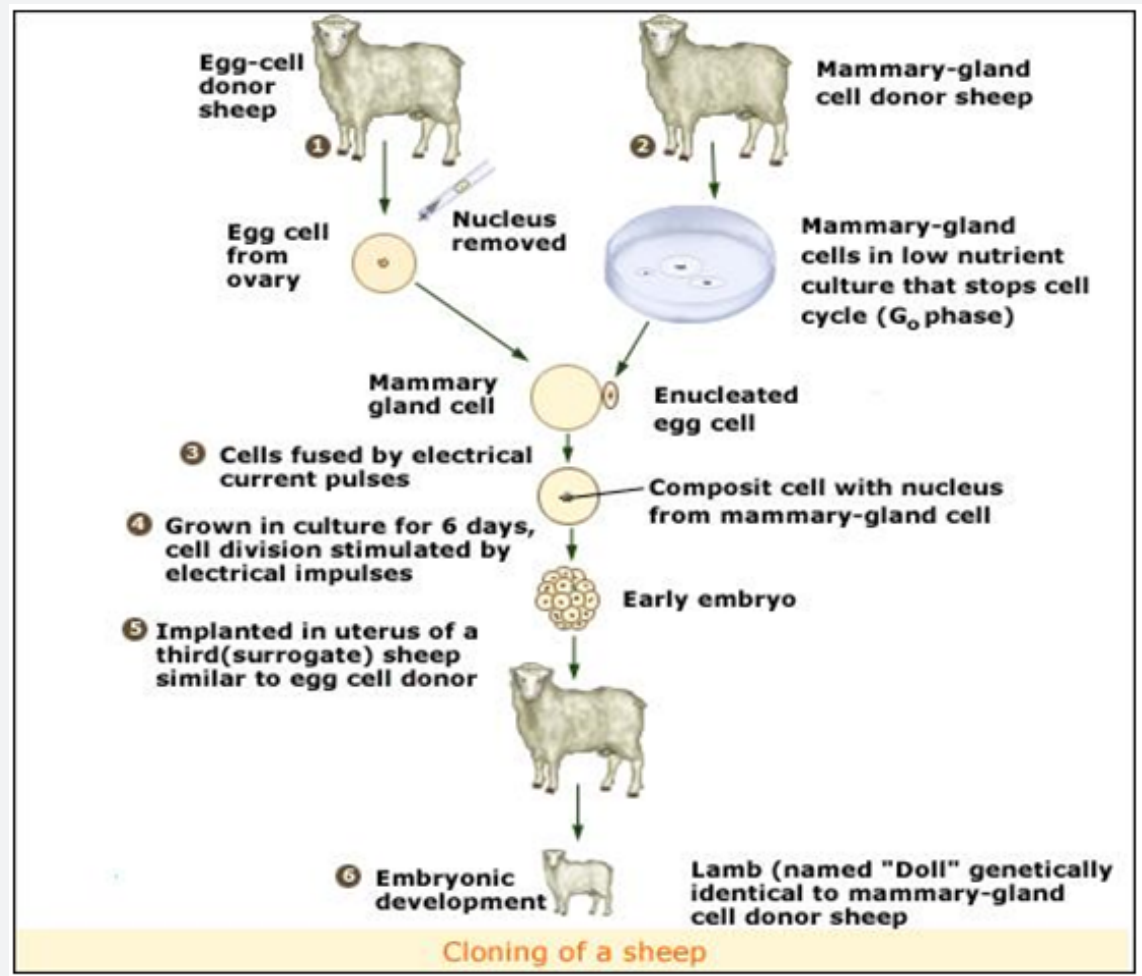

Figure 1: Cloning of sheep (Dolly).

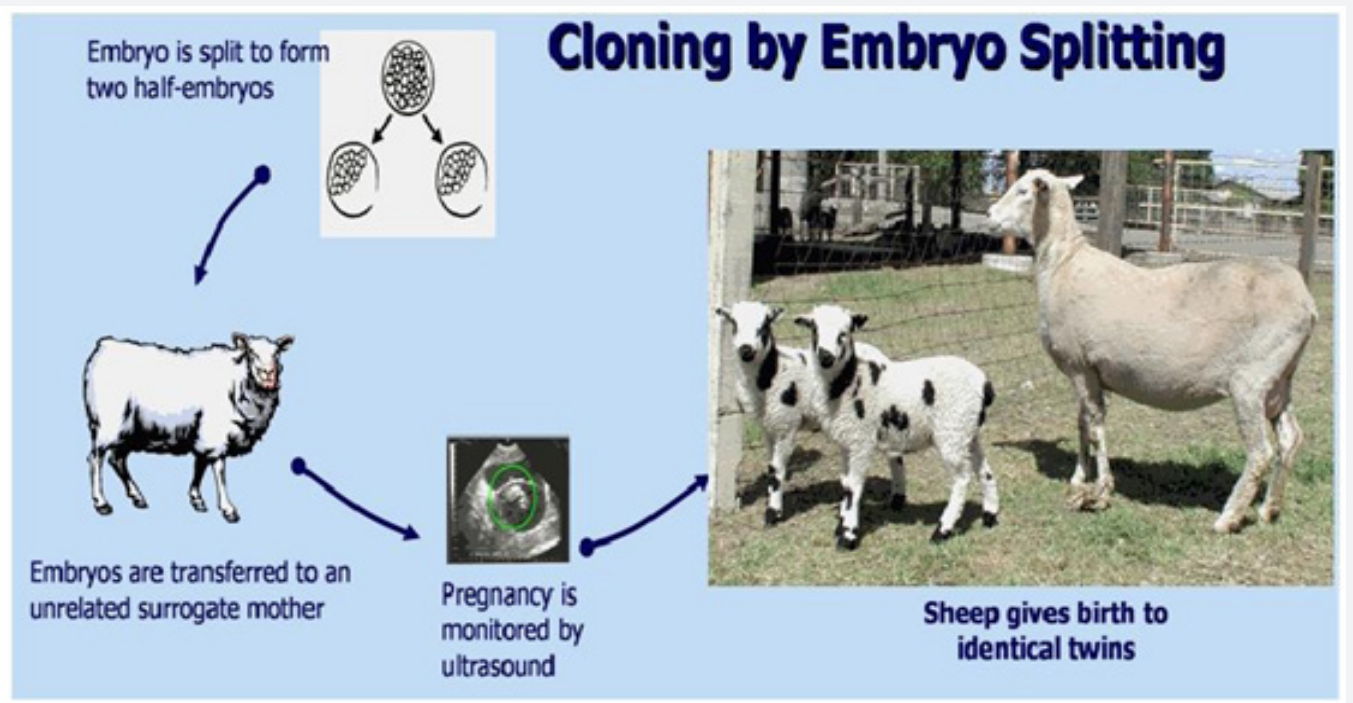

Figure 2: Cloning by embryo splitting.

\section{Application of cloning}

Rapid multiplication of desired livestock: Cloning could enable the rapid dissemination of superior genotypes from nucleus breeding flocks and herds, directly to commercial farmers. Genotypes could be provided that are ideally suited for specific product characteristics, disease resistance, or environmental conditions. Cloning could be extremely useful in multiplying outstanding F1 crossbred animals, or composite breeds, to maximize the benefits of both heterosis and potential uniformity within the colonal family [8]. These genetic gains could be achieved through the controlled release of selected lines of elite live animals or cloned embryos. More appropriately, given that cloning is not particularly efficient at present: a niche opportunity exists in the production of small numbers of cloned animals with superior genetics for breeding. These could be clones of performance tested animals, especially sires. This would be particularly relevant in the sheep and beef industries, where cloned sires could be used in widespread natural mating to provide an effective means of disseminating their superior genetics. This could be used as a substitute for artificial 
insemination, which in these more extensive industries is often expensive and inconvenient [40].

Animal conservation: Cloning can be used along with other forms of assisted reproduction to help preserve indigenous breeds of livestock, which have production traits and adaptability to local environments that should not be lost from the global gene pool. In some situations, inter-species NT and embryo transfer may be used to aid the conservation of some exotic species. At the very least, it is appropriate to consider the cryopreservation of somatic cells from these endangered animals as insurance against further Research model losses in diversity. Cryobanking of somatic cells from rare and endangered birds and animals against further losses of diversity or possible extinction of Wildlife to preserve endangered indigenous breeds of livestock adapted to particular environments [41].

\section{Research model}

Sets of cloned animals could be effectively used to reduce genetic variability and reduce the numbers of animals needed for some experimental studies. This could be conducted on a larger scale than is currently possible with naturally occurring genetically identical twins [42]. Lambs cloned from sheep selected either for resistance or susceptibility to nematode worms will be useful in studies aimed at discovering novel genes and regulatory pathways in immunology [43].

\section{Problems and prospects of animal cloning}

Placental abnormalities: A failure of the placenta to develop and function correctly is a common feature amongst clones. The majority of early pregnancy failures, before placentome formation, are attributed to an inadequate transition from yolk sac to allantoic-derived nutrition, with poor allantoic vascularisation in sheep [44]. Furthermore, there is reported evidence of immunological rejection contributing to early embryonic loss. Typically in cattle, $50 \%$ to $70 \%$ of pregnancies at day 50 are lost throughout the remainder of gestation and up to term. This is in stark contrast to only $0 \%$ to $5 \%$ loss with artificial insemination or natural mating over the same period. In extreme cases, placentomes are entirely absent at day 50. Shortly thereafter, these pregnancies fail. More commonly, cloned placentae only have half the normal number of placentomes, display compensatory overgrowth and are oedematous. Of particular concern are the losses in the second half of gestation; especially the occurrence of hydroallantois, i.e. the excess accumulation of fluid within the allantoises [45].

Post-natal viability: The viability of cloned offspring at delivery and up to weaning is reduced compared to normal, and this is despite greater than usual veterinary care. Data from our group shows that around $80 \%$ of cloned calves delivered at term are alive after 24 hours [46]. Two-thirds of the mortality within this period is due to a spinal fracture syndrome through the cranial epiphyseal plate of the first lumbar vertebrae or to deaths that occurred either in utero or from dystocia. Surviving newborn clones have altered neonatal metabolism and physiology, possibly due to placental abnormalities, and it takes time for these processes to adjust to normal [47].

At Agriculture Research, typically an additional 15\% of calves initially born alive die before weaning. In our experience, the most common mortality factors during this period are gastroenteritis and umbilical infections. Other abnormalities noted include defects in the cardiovascular, musculoskeletal and neurological systems, as well as susceptibility to lung infections and digestive disorders. Hydronephrosis is particularly common in sheep, with correspondingly elevated serum urea levels in some surviving clones.

Parturition difficulties: Intervention is often deemed necessary to deliver cloned offspring, as intervention gestation length in NT pregnancies is typically prolonged and the birth weight of cloned calves may be $25 \%$ heavier than normal. Newborn cloned calves display adrenal glands, so this extended gestation may be due to failure of the placentae to respond to foetal cortisol near term or to a lack of adreno corticotropic hormone release from the foetus. Oversized cloned offspring add to the birth complications. They are larger than artificially inseminated or naturally-mated controls. It has been reported that somatic cloned calves are heavier than embryonic clones. At Agriculture Research, the occurrence of prolonged gestation and the risk of dystocia initially prompted the delivery of clones by elective caesarean-section, following a brief exposure to exogenous corticosteroids.

Public opinion and food safety to genetically engineered and cloned animal: Public opinion against cloning is apparent throughout the world. According to The Euro Barometer poll conducted in 2008, 84\% of European Union citizens feel that the long-term effects of animal cloning on nature were unknown. The same poll also revealed that $61 \%$ European Union citizens of citizens believe the cloning of animals to be morally wrong (The Gallup Organization, 2008). A2005 Pew Initiative on Food and Biotechnology poll found that two-thirds of United States consumers indicated that they are uncomfortable with animal cloning in general. An earlier Gallup poll reportedly found that two-thirds considered animal cloning morally wrong [48].

Cloning has given rise to a massive ethical debate, including reports by bioethics committees and many books and articles. There are few enthusiastic advocates of cloning, but a number of bioethicists have tried to show that popular responses and even the more sophisticated philosophical arguments against cloning are naïve, and cannot be sustained. These commentators have argued that people's opposition to cloning is a Yuk reaction, which cannot stand up to reasoned argument. In a similar, defensive way, liberals have argued that while cloning may not be very desirable, it should not stop other people from doing it, because that would interfere with freedom [49].

The composition of food products derived from clones have found that they have the same composition as milk or meat from conventionally-produced animals [50]. Milk and 
meat from clones produced by embryo splitting and nuclear transfer of embryonic cells have been entering the human food supply for over 20 years with no evidence of problems. However, in 2001, the Center for Veterinary Medicine at the Food and Drug Administration (FDA) determined that it should undertake a comprehensive risk assessment to identify hazards and characterize food consumption risks that may result from Somatic cell nuclear transfer (SCNT) animal clones and therefore asked companies not to introduce these cloned animals, their progeny, or their food products (milk or meat) into the human or animal food supply. As there is no fundamental reason to suspect that clones will produce novel toxins or allergens, the main underlying food safety concern was whether the Somatic cell nuclear transfer (SCNT) cloning process results in subtle changes in the composition of animal food products [43].

Although the amount of data describing the health of the progeny of clones is more limited than the amount describing the health of animal clones themselves, there is an underlying biological assumption behind the predicted health and resultant food safety of the sexually-produced progeny of clones. The genetic remodeling process that occurs during gametogenesis (i.e. the production of eggs and sperm), is thought to naturally reset any epigenetic anomalies that might result from the cloning process. Sexual reproduction effectively corrects any programming errors that may have been introduced into the cloned parent's DNA, thereby resulting in the production of normal gametes and offspring. This assumption is supported by a study in mice where it has been observed that abnormalities present in cloned mice are not passed on to their sexuallyderived progeny. In addition, observations on the relatively small number of progeny of bovine and swine clones that have been born support the premise of normal development [51].

\section{Ethical issue of genetic engineering and cloning in respect to animal welfare}

Some scientific, governmental and religious organizations oppose reproductive cloning since serious ethical concerns have been raised by the future possibility of harvesting organs from clones [51]. The majority of religious organizations distinguish between reproductive and therapeutic cloning. Since cloning is an unnatural born of an individual, no one has the right to undertake it except God. Many embryos develop abnormally and die in utero, while others may be infertile or born with developmental defects, some of which are attributable to these so-called insertional problems [52]. Still other health issues may not become apparent until later in life. Transgenic animals often exhibit variable or uncontrolled expression of the inserted gene, resulting in illness and death [53]. In one study, ten transgenic piglets were followed from birth through puberty. Half of the animals died or had to be euthanized due to severe health problems during the investigation, indicating a high mortality rate among genetically engineered piglets. In addition, three of the surviving piglets showed decreased cardiac output [54].
The genetic modification of sheep containing an extra copy of a growth hormone gene resulted in animals who reportedly grew faster, leaner, and larger than those conventionally bred; produced more wool; or produced milk for prolonged periods. Developing more economically profitable sheep reportedly resulted in negative welfare side effects from the excess growth hormone, including increased incidences of diabetes and susceptibility to parasites [55]. Cloning research also reveals abnormalities and high failure rates, problems widely acknowledged by scientists in the field and potentially indicative of poor animal welfare [56]. Seemingly healthy bioengineered animals are at risk for a variety of defects. All cloned babies have some sort of error. The list of problems from which clones have suffered is extensive, including diabetes, enlarged tongues, malformed faces, intestinal blockages, shortened tendons, deformed feet, weakened immune systems, respiratory distress, circulatory problems, and dysfunctional hearts, brains, livers, and kidneys.

\section{Future perspectives of transgenesis}

The techniques for obtaining transgenic animals in species of agricultural interest are still inefficient. Some approaches that may overcome this problem are based on cloning techniques. Using these techniques it is feasible to reduce to less than $50 \%$ the number of embryo receptor females, which is one of the most important economic limiting factor in domestic species. It would also facilitate the further proliferation of transgenic animals. Recent results relate these techniques with still low success rates [57], high rates of perinatal mortality and variable transgenic expression that requires to be evaluated before generalizing their application. Considerable effort and time is required to propagate the transgenic animal genetics into commercial dairy herds. Rapid dissemination of the genetics of the parental animals by nuclear transfer could result in the generation of mini herds in two to three years. However, the existing inefficiencies in nuclear transfer make this a difficult undertaking. It is noteworthy that the genetic merit of the 'cloned' animals can be fixed, while continuous genetic improvements is introduced in commercial herds by using artificial insemination breeding programs [58].

In an alternative scenario of herd expansion, semen homozygous for the transgene may be available in four to five years. Extensive breeding programs will be critical in studying the interaction and co-adaptation of the transgene(s), with the background polygenes controlling milk production and composition. Controlling inbreeding and confirming the absence of deleterious traits so that the immediate genetic variability introduced by transgenesis is transformed into the greatest possible genetic progress is equally critical.

\section{Cloning in Africa}

The first healthy cloned calf in South Africa in 2003 was successful called Futhi [59]. It is African's first cloned (nuclear transferred) healthy calf, produced with handmade cloning. 
In situations regarding our country, there is no any reliable research conducted on genetic engineering and cloning. It is also difficult to perform or apply the technology not only because of technological insufficiency and financial limitation but also lack of skill and knowledge [60-62].

\section{Conclusion and Recommendations}

Genetic engineering is the processes of producing genetically modified animals by using different techniques such as exogenous pronuclear DNA microinjection in zygotes, injection of genetically modified embryonic stem cells into blastocysts and retrovirus mediated gene transfer. It has advanced application in various sectors including increased animal production and productivity, increase animal disease resistance and biomedical application. Cloning is the process of producing genetically identical individual to the donor cells by using different techniques such as somatic cell nuclear transfer and embryo splitting [63-65]. It has various applications such as rapid multiplication of desired livestock, animal conservation and research model [66,67]. Even if, transgenic and cloned animals have wide range application and the science is very interesting and valuable, many challenges from the food safety, animal welfare, public and social acceptance points of view, socio-cultural and religious obstacles and technical inefficiency are headache for the technology [68].

In most of developing country including Ethiopia have no attempt of animal genetic engineering and cloning which could be attributed to lack of knowledge and skill, technological insufficiency as well as financial limitation. Therefore; based on the above conclusion the following recommendations are forwarded:

a. Further study and research are needed to be conducted to improve the techniques and increase the successes rate of genetic engineering and cloning.

b. Much work is to be done on creating public awareness on genetic engineering and animal cloning to avert the sociocultural and religious problems facing this technological advancement.

c. Veterinarian should acquire basic knowledge about the application and techniques of animal genetic engineering and cloning and this should be part of the academic curriculum.

d. Concerned organizations/institution in developing country including Ethiopia should be involved in technology transfer researches and make use of the advantages of animal genetic engineering and cloning.

\section{References}

1. Murray JD, Anderson GB (2000) Genetic engineering and cloning may improve milk, livestock production. California Agriculture, Phil Schermeister. Pp: 57-60.

2. Houdebine LM (2005) Use of transgenic animals to improve human health and animal production. Reprod Domest Anim 40(4): 269-281.

3. Sullivan EJ, Pommer J, Robl JM (2008) Commercializing genetically engineered animal biomedical products. Reprod Fertil Dev 20: 61-65.
4. Lillico SG, McGrew MJ, Sherman A, Sang HM (2005) Transgenic chickens as bioreactors for protein-based drugs. Drug Discovery 10(3): 191-196.

5. Richt JA, Kasinathan P, Hamir AN, Castilla J, Sathiyaseelan T, et al. (2007) Production of cattle lacking prion protein. Nat Biotechnol 25(1): 132-138.

6. Lai L, Kang JX, Li R, Wang J, Witt WT, et al. (2006) Generation of cloned transgenic pigs rich in omega-3 fatty acids. Nat Biotechnol 24(4): 435436.

7. Reik W (2007) Stability and flexibility of epigenetic gene regulation in mammalian development. Nature 447(7143): 425-432.

8. Wells DN (2005) Animal cloning, problems and prospects. Rev Sci Tech 24(1): 251-264.

9. Wilmut I (2003): Human cells from mice cloned embryos in research andtherapy. Clon Ste Cel 5:163-164.

10. MacArthur JA, Potter M, Harding E (2006) The welfare implications of animal breeding and breeding technologies in commercial agriculture. Livestock Sci 103: 270-281.

11. World Health Organisation for animal (2010) Definition of animal welfare, glossary. Terrestrial Animal Health Code Pp. 114.

12. Larson G1, Karlsson EK, Perri A, Webster MT, Ho SY, Peters J, et al. (2012): Rethinking dog domestication by integrating genetics, archeology and biogeography. Proc Natl Acad Sci U S A 109(23): 88788883.

13. John G (2001) Evaluation of meat products from cloned cattle: Biological and biochemical properties. Clon Ste Cel 23: 345-349.

14. Wilmut I, Schnieke AE, McWhir J, Kind AJ, Campbell KH (1997) Viable offspring derive from fetal and adult mammalian cells. Nature 385(6619): 810-813.

15. Zhou Q, Renard JP, Le Friec G, Brochard V, Beaujean N, et al. (2003) Generation of fertile cloned rats by regulating oocyte activation. Science 302(5648):1179.

16. Kap G (2002) Cell and Molecular Biology: concepts and Experiment (3rd edn) New York, Willey, USA Pp. 785.

17. Klug, W.S. and Cumming, M.R.(2002): Concepts of Genetics, (7th edn). Prentice Hall, New Jersey , USA Pp.800.

18. Melo EO, Canavessi AM, Franco MM, Rumpf R (2007) Animal trangenesis: state of the art and applications. J Appl Genet 48(1): 4761.

19. Robl JM, Wang Z, Kasinathan P, Kuroiwa Y (2007) Transgenic animal production and animal biotechnology. Theriogenology 67(1): 127-133.

20. Denning C, Priddle H (2003) New frontiers in gene targeting and cloning: success, application and challenges in domestic animals and human embryonic stem cells. Reproduction 126(1): 1-11.

21. Whitelaw CB, Lillico SG, King T (2008) Production of transgenic farm animals by viral vector-mediated gene transfer. Reprod. Domest. Reprod Domest Anim 2: 355-358.

22. Park F (2007) Lentiviral vectors: are they the future of animal transgenesis. Physiol Genomics 31(2): 159-173.

23. Lewin HA (2001) Disease resistance and immune response genes in cattle: strategies for their detection and evidence of their existence. J Dairy Sci 72(5): 1334-1348.

24. Edfors LI, Petersson H, Gahne B (2002) Performance of pigs with or without the intestinal receptor for Escherichia Coli K88. Anim Prod 42 : 381-387.

25. Hill JR, Schlafer DH, Fisher PJ, Davies CJ (2002) Abnormal expression of trophoblast major histocompatibility complex class I antigens in cloned 
bovine pregnancies is associated with a pronounced endometrial lymphocytic response. Biol Reprod 67(1): 55-63.

26. Hollis DE, Chapman RE, Panaretto BA, Moore GP (2004) Morphological changes in the skin and wool fibers of Merino sheep infused with mouse epidermal growth factor. Aust J Biol Sci 36(4): 419-34.

27. Noble MS, Rodriguez-Zas S, Cook JB, Bleck GT, Hurley WL, et al. (2002) Lactational performance of first parity transgenic gilts expressing bovine \pm -lactalbumin in their milk. J Anim Sci 80(4): 1090-1096.

28. Brundige DR, Maga EA, Klasing KC, Murray JD (2010) Consumption of pasteurize human lysozyme transgenic goats' milk alters serum metabolite profile in young pigs. Transgenic Res 19(4): 563-74.

29. Brundige DR1, Maga EA, Klasing KC, Murray JD (2008) Lysozyme transgenic goats' milk influences gastrointestinal morphology in young pigs. J Nutr 138(5):921-926.

30. Malcarney HL, Bonar F, Murrell GA (2005) Early inflammatory reactions after rotator cuff repair with porcine small intestine submucosal implant: a report of 4 cases. Am J Sports Med 33(6): 907-911.

31. Colman A, Kind A (2000) Therapeutic cloning: concepts and practicalities. Trends Biotechnol 18(5): 192-196.

32. Das SK, Majumdar AC, Sharma GT (2003) In-vitro development of reconstructed goat oocyte after somatic cell nuclear transfer with fetal fibroblast cells. Smal Rumin Res 48: 217-225.

33. Collas P, Håkelien AM (2003) Teaching cells new tricks. Trends Biotechnol 21(8): 354-361.

34. Kind A, Schnieke A (2008) Animal pharming, two decades on. Transgenic Res 17(6):1025-1033.

35. Houdebine LM (2009) Production of pharmaceutical proteins by transgenic animals. Comp. Immunol Comp Immunol Microbiol Infect Dis 32(2): 107-121.

36. Podoly E, Bruck T, Diamant S, Melamed BN, Weiss A, et al. (2008) Human recombine but yrylcholinesterase purified from the milk of transgenic goats interacts with beta-amyloid fibrils and suppresses their formation in vitro. Neurodegener Dis 5(3-4): 232-236.

37. Tseng YL, Dor FJ, Kuwaki K, Ryan D, Wood J, et al. (2004) Bone marrow transplantation from alpha1,3-galactosyltransferase gene-knockout pigs in baboons. Xenotransplantation 11(4): 361-370.

38. Lai L, Kolber-Simonds D, Park KW, Cheong HT, Greenstein JL, et al. (2002) Production of alpha-1,3-galactosyltransferase knockout pigs by nuclear transfer cloning. Science 295(5557): 1089-1092.

39. Tamashiro KL, Wakayama T, Akutsu H, Yamazaki Y, Lachey JL, et al. (2002): Cloned mice have an obese phenotype not transmitted to their offspring. Nat Med 8(3): 262-267.

40. Forsyth JT, Troskie HE, Brophy B, Wells DN, Laible G (2005) Utilising pre-implantation genetic diagnosis and OPU-IVP-ET to generate multiple progeny of predetermined genotype from cloned transgenic heifers. Reprod. Fertil Dev 32: 232-245.

41. Rudenko L, Matheson JC, Adams AL, Dubbin ES, Greenlees KJ (2004) Food consumption risks associated with animal clones. Cloning Stem Cells 6(2): 79-93.

42. Rudenko L, Matheson JC (2007) The US FDA and animal cloning: risk and regulatory approach. Theriogenology 67(1): 198-206.

43. Polejaeva IA, Chen SH, Vaught TD, Page RL, Mullins J, et al. (2000) Cloned pigs produced by nuclear transfer from adult somatic cells. Nature 407(6800): 86-90.

44. De Sousa PA, King T, Harkness L, Young LE, Walker SK, et al. (2001) Evaluation of gestational deficiencies in cloned sheep fetuses and placentae. Biol Reprod 65(1): 23-30.
45. Lanza RP, Cibelli JB, Faber D, Sweeney RW, Henderson B, et al. (2001) Cloned cattle can be healthy and normal. Science 294(5548):18931894.

46. Chavatte-Palmer P, Heyman Y, Richard C, Monget P, LeBourhis D, et al (2002) Clinical, hormonal and hematologic characteristics of bovine calves derived from nuclei from somatic cells. Biol Reprod 66(6): 15961603.

47. Wells DN, Forsyth JT, McMillan V, Oback B (2004) The health of somatic cell cloned cattle and their offspring. Cloning Stem Cells 6(2): 101-110.

48. Former FJ (2005) Attempts to produce monozygotic quadruplets in cattle by blastomeric separation. Vet Rec 2: 234-254.

49. Jaenisch R (2003) The biology of nuclear cloning and the potential of embryonic stem cells for transplantation therapy.

50. Takahashi S, Ito Y (2004) Evaluation of meat products from cloned cattle: Biological and biochemical properties. Cloning Stem Cells 6(2): 165-171.

51. Pence A, Gregory E (2005) Cloning after Dolly: Who has still afraid? Rowman and Little field. Transplant Proc Natl Acad Sci, USA, 36:318831895.

52. NRCNAS (2002) Animal Biotechnology, science based concerns. The National Academies Press, Washington, USA.

53. Carter DB, Lai L, Park KW, Samuel M, Lattimer JC, et al. (2002) Phenotyping of transgenic cloned piglets. Cloning Stem Cells 4(2): 131145.

54. CSIRO (Common wealth Scientific and Industrial Research Organization) (2002) GM sheep grow bigger, produce more milk and wool.

55. Wall RJ, Powell AM, Paape MJ, Kerr DE, Bannerman DD, et al. (2005) Genetically enhanced cows resist intramammary Staphylococcus aureus infection. Nat Biotechnol 23(4): 445-51.

56. Panarace M, Agüero JI, Garrote M, Jauregui G, Segovia A, et al. (2007) How healthy are clones and their progeny: 5 years of field experience. Theriogenology 67(1): 142-151.

57. Edwards JL, Schrick FN, McCracken MD, van Amstel SR, Hopkins FM, et al. (2003) Cloning adult farm animals: a review of the possibilities and problems associated with somatic cell nuclear transfer. Am J Reprod Immunol 50(2): 113-123.

58. Karatzas CN (2003) Designer milk from transgenic clones. Nat Biotechnol 21(2): 138-139.

59. Vajta G, Gjerris M (2006) Science and technology of farm animal cloning: state of the art. Anim Reprod Sci 92(3-4): 211-230.

60. Baguisi A, Behboodi E, Melican DT, Pollock JS, Destrempes MM, et al. (1999) Production of goats by somatic cell nuclear transfer. Nat Biotechnol 17(5):456-461.

61. Chesné P, Adenot PG, Viglietta C, Baratte M, Boulanger L, et al. (2002) Cloned rabbits produced by nuclear transfer from adult somatic cells. Nat Biotechnol 20(4): 366-369.

62. Lee BC, Kim MK, Jang G, Oh HJ, Yuda F, et al. (2005) Dogs cloned from adult somatic cells. Nature 436(7051): 641.

63. Li Z, Sun X, Chen J, Liu X, Wisely SM, et al. (2006) Cloned ferrets produced by somatic cell nuclear transfer. Dev Biol 293(2): 439-448.

64. Golovan SP, Meidinger RG, Ajakaiye A, Cottrill M, Wiederkehr MZ, et al. (2001) Pigs expressing salivary phytase produce low- phosphorus manure. Nat Biotechnol 19(8): 741-745.

65. Shi D, Lu F, Wei Y, Cui K, Yang S, et al. (2007): Buffalos cloned by nuclear transfer of somatic cells. Biol Reprod 77(2): 285- 291. 
66. Wakayama T, Perry AC, Zuccotti M, Johnson KR, Yanagimachi R (1998) Full-term development of mice from enucleated oocytes injected with cumulus cell nuclei. Nature 394(6691): 369-374

67. Wani NA, Wernery U, Hassan FA, Wernery R, Skidmore JA (2010) Production of the first cloned camel by somatic cell nuclear transfer. Biol Reprod 82(2): 373-379.

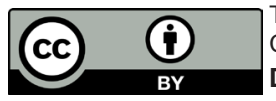

This work is licensed under Creative Commons Attribution 4.0 Licens DOI: 10.19080/JDVS.2017.04.555629
68. Zhang J, Li L, Cai Y, Xu X, Chen J, et al. (2008) Expression of active recombinant human lactoferrin in the milk of transgenic goats. Protein Expr Purif 57(2):127-135

\section{Your next submission with Juniper Publishers} will reach you the below assets

- Quality Editorial service

- Swift Peer Review

- Reprints availability

- E-prints Service

- Manuscript Podcast for convenient understanding

- Global attainment for your research

- Manuscript accessibility in different formats

( Pdf, E-pub, Full Text, Audio)

- Unceasing customer service

Track the below URL for one-step submission https://juniperpublishers.com/online-submission.php 